Volume 7, Issue 1, 1-5 Pages

Research Article | Open Access

ISSN (Online)- 2378-7031

DOI :

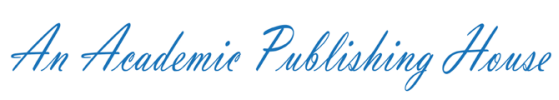

\title{
Transformational Leadership of the Principal on School Performance in Indonesia
}

\author{
Jusrin Efendi Pohan' ${ }^{1}$ Edy Suprayetno ${ }^{2}$
}

${ }^{1}$ Indonesian Language Education Department, Universitas Prima Indonesia, Indonesia.

${ }^{2}$ Indonesian Language Education Department, Universitas Muhammadiyah Sumatera Utara, Indonesia.

\begin{abstract}
This research is motivated by the low ability of school principals in making decisions. It can be seen that many parties are marginalized by this decision. This study uses a quantitative approach with a survey method involving 82 teachers as respondents. Collecting data by using questionnaires to respondents, interviews, and observations. Data analysis was carried out by $t$-test and F-test. Data analysis was carried out by simple regression to determine the relationship of each variable $X$ to $Y$, then using multiple regression formulas to determine the contribution of X1 and X2 together to variable $Y$. Before testing the hypothesis First, the classical assumption test is performed, which consists of normality assumption test, heteroscedasticity test, serial correlation test and multicollinearity test, and the second is regression analysis test. This study resulted in the finding that the principal's transformational leadership can improve school performance.
\end{abstract}

KEYWORDS: transformational leadership; school performance; principal

\section{INTRODUCTION}

The establishment of harmonization between leaders and subordinates will form togetherness in carrying out tasks. This requires the expertise of aleaderin overcoming problems that are both vertical and horizontal, so that the organization can run well. Leaders with a high degree of structure building perform a variety of task-related behaviors, such as setting deadlines, setting performance standards, and monitoring performance levels (Hughes and Curphy, 2012).

Disintegration between interests and goals to be achieved often creates disharmony between leaders and subordinates (Daghistani, 2017). This disharmony will result in ambiguity forsubordinatesinworking optimallyaccordingtoestablished operational standards. The establishment of a leader leads to a policy that prioritizes common interests. Educational leadership performance in schools is characterized by weakness, complexity, poor creativity, contradiction, and discontinuity (Alalfi, 2015). The social structure in which both women and men have to work is rapidly expanding, and the desire to fulfill responsibilities in work and family life makes it necessary to establish a balance between work and personal life (Yuldirim, 2017).

One of the organizations that requires strong, wise, and committed leadership in setting goals is the principal. The principal becomes the driving force in formulating plans, strategies, achievements in determining policies. The right policies will lead schools to achieve mutual success in educating future generations. On the other hand, the wrong policy will have a negative impact on schools, usually people do not trust the school as a place to study.

Referring to the research that has been done by Korkmaz (2008) about principal leadership is very closely related to the role of the leader and leadership style is very necessary. Principal leadership can be seen from teacher satisfaction at work (Yılmaz and Ceylan, 2011). The organizational role process model refers to the way in which employees reach out to their roles and how roles are reflected by employees in their behavior.One of the appropriate leadership models used in building a collaborative decision-making culture is the transformational leadership model. This transformational leadership model leads to providing individual support, providing intellectual stimulation, and setting high performance expectations for subordinates (Leithwood and Jantzi, 1997).Transformational leadership is conceptualized as involving a series of behaviors designed to inspire, empower, and motivate others to transcend and achieve higher levels of goals and missions(Kim, et al, 2017).

In addition, transformational leadership emphasizes the process of influencing individuals and mobilizing power to change social systems and reform institutions (Komariah and 
Triatna, 2006). That is, the dimensions of transformational leadership are in line with times of rapid change in changing contexts (Bush \& Middlewood, 2005; Leithwood, et al, 1999). On the other hand, the main roles of transformational leadership include creating a vision, mobilizing commitment to the vision, and institutionalizing change throughout the organization (Jonyo, 2017).

The dimensions of transformational leadership with the 4 (four)I concept are (1) idealized influence, (2) inspirational motivation, (3) intellectual stimulation, and (4) individualized consideration (Komariah and Triatna, 2006; Barling, et al, 2010). A transformational leadership model in the school context contains six dimensions, namely supporting the development of vision and goals, building a collaborative decision-making structure, exemplifying good professional practices, providing individual support, providing intellectual stimulation, and setting high performance expectations(Cheng, 2001). The main set of basic leadership practices that are useful in almost every school. This model classifies several specific dimensions into the following three broad groups of leadership practices.

First, setting direction, namely building a common vision, creating consensus on goals and priorities, and building high performance expectations. Second, developing human resources, including: providing individual support, offering intellectual stimulation, and providing examples of important values and practices. Third, redesign the organization; includes building a collaborative culture, creating and maintaining shared decision-making structures and processes, and building relationships with parents and the larger community (Yu et al., 2002). These different leadership roles can transform schools into communities and inspire a variety of commitments, powers, and services that make schools indistinguishable from other community institutions (Raihani, 2010).

\section{RESEARCH METHODS}

This type of research includes quantitative research conducted with analytical descriptive surveys that describe various factors that influence transformational leadership variables, namely organizational climate and organizational culture on service quality. This research was conducted in Medan City High School and the object of the research was the principal. The independent variables in this study are organizational climate (X1), organizational culture (X2) and service quality (Y). In operating the research variables, the researcher used a Likert scale. In line with the opinion of Sugiyono (2004)that the Likert scale is a scale used to measure attitudes, opinions and perceptions of a person or group of people about social phenomena. The population in this study were 450 people.

Determination of the sample size using the Slovin formula obtained a research sample of 82 people. The data collection technique was carried out by field research with a questionnaire instrument, observation with an observation guide instrument, and interviews with an interview guide. Data analysis was carried out by simple regression to determine the relationship of each variable X to Y, then using multiple regression formulas to determine the contribution of X1 and X2 together to variable Y.

Before testing the hypothesis, the classical assumption test is first performed, which consists of the normality assumption test, the heteroscedasticity test, the serial correlation test and the multicollinearity test, and the second is a regression analysis test.

After testing the classical assumptions and regression analysis, then hypothesis testing is carried out. Hypothesis testing aims to determine the effect of variable $\mathrm{X}$ on variable Y, either individually or jointly. Testing the hypothesis of the $\mathrm{X}$ variable on the $\mathrm{Y}$ variable individually is carried out by using the $\mathrm{t}$ test. Meanwhile, the hypothesis testing of the $\mathrm{X}$ variable against $Y$ was jointly carried out with the F test.

\section{FINDINGS AND DISCUSSION}

After the research was conducted, the data or the results of distributing questionnaires for the organizational climate variable data (Y) showed that the lowest score was 40 and the highest score was 75. Thus, the lowest and highest scores were obtained, then the range of scores was 35 (40-75). These numbers after being analyzed resulted in an average score $($ Mean $)=59.0488$, the mean $($ median $)=58.8333$, the mode $($ mode $)=53.00$, the variance $($ variance $)=69.4050$, and the deviation standard (standard deviation) $=8,3310$.

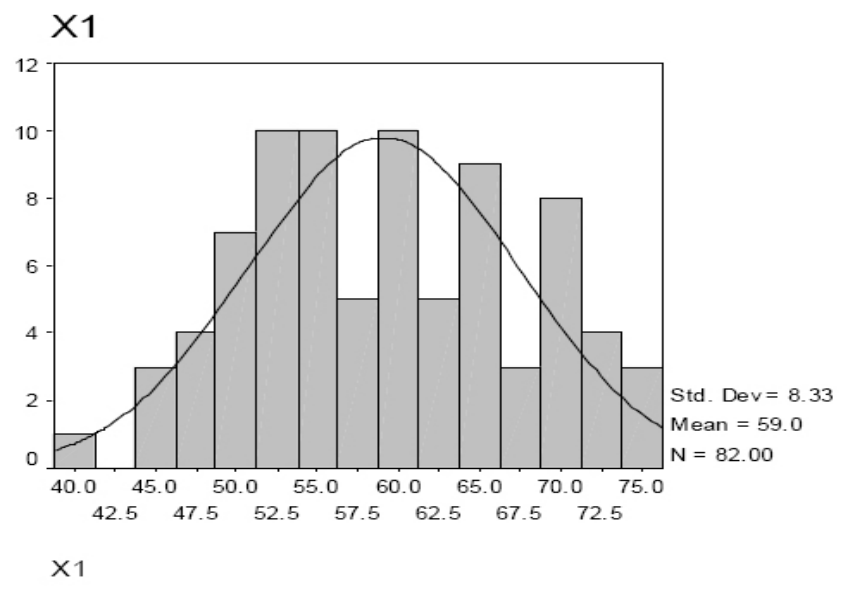

On the aspect of organizational culture, it can be seen from the activities of the teachers as a whole every working day, starting from the discipline of coming to work, resting and going home. The teacher's job is seen from whether the teacher is afraid of the punishment that is applied if he does not complete the task well. Teachers work or complete tasks because of the element of fear, it is clear that the work culture of the teachers is not yet aware. However, teachers work with discipline when they come to work, take breaks, go home, and do assignments on time without fear of superiors, fear of punishment, but work with pleasure. Teachers feel that doing assignments is part of their lives will become a habit at work and become a work culture. 
The actions taken by the teacher should be enthusiastic and optimistic about success. The teacher's optimistic attitude can be seen in the teacher's confidence in doing the task in accordance with the operational standards that have been set. The position of the principal must be able to foster an optimistic attitude of the teacher in working in accordance with the expertise of the teacher, so that the teacher will feel comfortable at work. With this optimistic attitude, the teacher will always be confident that he or she will be able to complete the task on time.

The results of distributing questionnaires were given to a sample of 82 people for organizational culture variable data showing that the lowest score was 35 and the highest score was 75. Thus, the lowest and highest scores were obtained, then the range of scores was 40 (35-75). These numbers after being analyzed resulted in an average score (mean) $=58.2195$, the mean $($ median $)=58.2857$, mode $($ mode $)=$ 57.00 , variance (variance) $=81.4327$, and standard deviation (standard deviation) $=9.0240$. To make it clearer, see the following diagram.

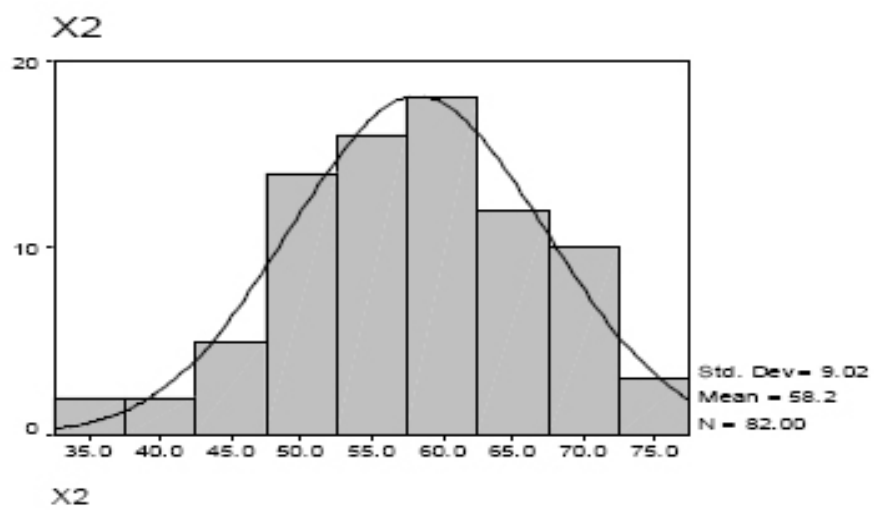

Furthermore, the data obtained from the results of distributing questionnaires on the dependent variable, namely service quality (Y), shows that the final result has the lowest score of 36 and the highest score of 75 . Thus, the range of scores is 39 (36-75). After further analysis, these numbers resulted in an average score (mean) $=57.3902$, the mean $($ median $)=56.3077$, mode $($ mode $)=56.00$, variance (variance $)=86.8582$, and standard deviation $=9.3198$.

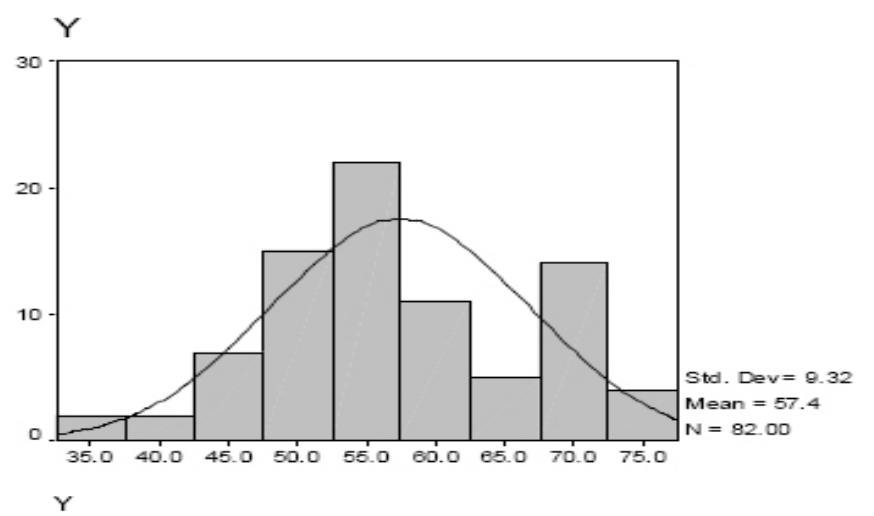

Referring to the data above, the next step is the normality test with the help of SPSS, organizational climate variables (X1) and organizational culture (X2) on service quality (Y) indicate that the data (dots) spread around the diagonal line and follow the diagonal line. That is, regression is feasible to use to predict organizational climate variables (X1) and organizational culture (X2) on service quality (Y).

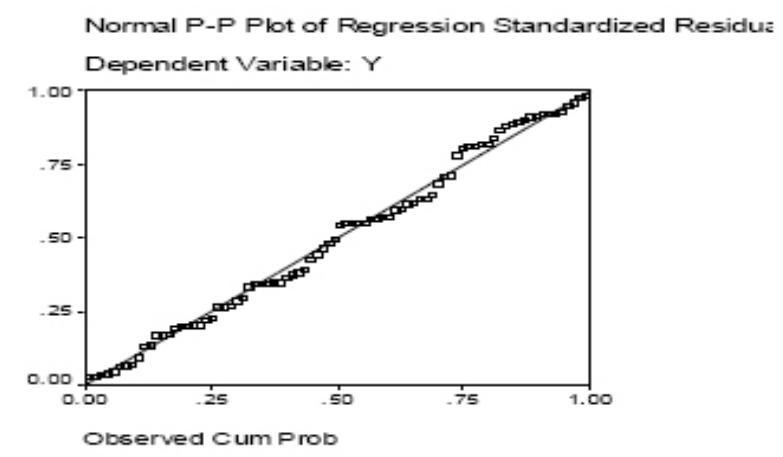

The picture above shows that the normal probability shows the distribution of the data on the chart, there is a strong correlation between the expected cumulative probability and the observed cumulative probability, so that it meets the requirements for normality.

After that, the statistical hypothesis testing for the first and second hypotheses was carried out using the t-test, while the third hypothesis was carried out by the F-test. multiple. This is shown in the following simple correlation coefficient

\section{Simple Correlation Coefficient}

Correlations

\begin{tabular}{|ll|r|r|r|}
\hline & & \multicolumn{1}{|c|}{$\mathrm{Y}$} & \multicolumn{1}{c|}{$\mathrm{X} 1$} & \multicolumn{1}{c|}{$\mathrm{X} 2$} \\
\hline Pearson Correlation & $\mathrm{Y}$ & 1.000 & .675 & .907 \\
& $\mathrm{X} 1$ & .675 & 1.000 & .652 \\
& $\mathrm{X} 2$ & .907 & .652 & 1.000 \\
\hline Sig. (1-taled) & $\mathrm{Y}$ &. & .000 & .000 \\
& $\mathrm{X} 1$ & .000 &. & .000 \\
& $\mathrm{X} 2$ & .000 & .000 & \\
\hline $\mathrm{N}$ & $\mathrm{Y}$ & 82 & 82 & 82 \\
& $\mathrm{X} 1$ & 82 & 82 & 82 \\
& $\mathrm{X} 2$ & 82 & 82 & 82 \\
\hline
\end{tabular}

In addition to simple correlation coefficients, researchers also tested with multiple correlations. From the calculation results, it is obtained that the magnitude of the multiple correlation coefficient between organizational climate and organizational culture with service quality is 0.913 , meaning that the close relationship between organizational climate and organizational culture with service quality is $91.3 \%$. This relationship is very strong because it is between 0.80 - 1,000, which means that the organizational climate and organizational culture improve and the quality of service also increases. For more details can be seen in the following table.

\section{Multiple Correlation Coefficient}

Model Summary

\begin{tabular}{|l|r|r|r|r|}
\hline Model & R & R Square & $\begin{array}{c}\text { Adjusted } \\
\text { R Square }\end{array}$ & $\begin{array}{c}\text { Std. Error of } \\
\text { the Estimate }\end{array}$ \\
\hline 1 & $.913^{\mathrm{a}}$ & .834 & .830 & 3.8394 \\
\hline
\end{tabular}

a. Predictors: (Constant), X2, X1 
F Test Hypothesis Testing

ANOVA

\begin{tabular}{|c|c|c|c|c|c|c|}
\hline Model & & $\begin{array}{l}\text { Sum of } \\
\text { Squares }\end{array}$ & df & Mean Square & $\mathrm{F}$ & Sia. \\
\hline \multirow[t]{3}{*}{-} & Regression & 5870.961 & 2 & 2935.480 & 199.135 & .000 \\
\hline & Residual & 1164.551 & 79 & 14.741 & & \\
\hline & Total & 7035.512 & 81 & & & \\
\hline
\end{tabular}

a. Predictors: (Constant), X2, XI

\section{b. Dependent Variable: $Y$}

Based on the results of testing the $\mathrm{F}$ test hypothesis, Fcount is 199.135 , while the critical value of the Ftable value with degrees of freedom is the numerator 2 and the denominator 79 at $(0.05)$ of 3.11 . Thus, Fcount $(199,135)>$ Ftable $(3,11)$, so it is clear that Ho is rejected and Ha is accepted. This shows that together the organizational climate and organizational culture can improve service quality.

\section{DISCUSSIONS}

Referring to the results of the research above, the researcher describes the variables of this study, namely organizational climate and organizational culture that can improve service quality. This shows that the dimensions of transformational leadership with the 4-I concept, namely (1) idealized influence, (2) inspirational motivation, (3) intellectual stimulation, and (4) individualized consideration (Spadaro, 2017).

First, idealized influence is defined as behavior that results in the respect and confidence of the people they lead. Idealized influence implies sharing of risk through consideration of staff needs above personal needs and ethical moral behavior. Second, inspirational motivation, reflected in behavior that always provides challenges for the work done by staff and pays attention to the meaning of work for staff. The leader demonstrates or demonstrates commitment to organizational goals through staff-observable behavior. The leader is a passionate motivator to keep staff enthusiastic and optimistic.

Third, intellectual stimulation, namely leaders who practice innovations. His leadership attitude and behavior are based on developed science and intellectually able to translate it into productive performance. As intellectuals, the leader always explores new ideas and creative solutions from the staff and does not forget to always encourage staff to learn and practice new approaches in doing work. Fourth, individualized consideration, the leader reflects himself as someone who is attentive in listening and following up on complaints, ideas, expectations, and all inputs given by staff.

The principal's transformational leadership model is very appropriate to be applied to improve school management. Principals can do with strategies that are able to bridge the aspirations of these teachers. First, the self-motivation strategy. This strategy aims to implement transformational leadership for school principals by motivating themselves so that they can work professionally. This is due to the motivation of the principal to be able to work professionally, this will cause the work carried out by the principal to be carried out properly.

Second, motivate subordinates. This strategy is carried out by the principal by motivating teachers and staff to work professionally and must be carried out by the principal properly. Teachers can work with professionals teaching students well. Apart from teachers, principals also motivate staff to work professionally by preparing school administration. Third, cultivate self-confidence. This strategy focuses that principals increase the confidence of teachers and staff by giving full freedom to be creative.

Fourth, maximize the potential of teachers and staff. This strategy is used by principals to maximize the potential of teachers and staff properly. Maximizing the potential of teachers can provide a stimulus for teachers to carry out the learning process professionally. Students will be able to understand every lesson taught by the teacher according to the ability of students. Principals with transformational leadership models can maximize the potential of teachers and staff.

Fifth, have a high commitment. The strategy carried out by the principal conveys a high commitment in advancing the school to the teachers and staff. This means that principals who have a high commitment to advancing the school will make teachers and staff have a high commitment to advancing the school. If the principal, teachers, and staff can jointly have a high commitment to advancing the school, the school will become a superior school.

Sixth, improve self-integrity. This strategy is used to improve the integrity of self, teachers and staff by having confidence in the principal. Teachers and staff are given full confidence to carry out the tasks assigned by the principal. All teachers feel togetherness in carrying out their duties according to their capacity and targets to be achieved. The principal can instruct teachers and staff by helping others in their assignments. Every teacher consciously does the teaching task without being burdened.

\section{CONCLUSION}

Based on the discussion and findings obtained in this study, several conclusions can bedrawnas follows. Transformational leadership is very suitable for principals in carrying out the management process to make decisions. The principal not only embraces subordinates and staff, but can improve the quality of the school. Transformational leadership is very much different from transactional leadership, where transformational leadership is more concerned with togetherness and diversity in thought and work. The four dimensions of transformational leadership, namely idealized 
influence, inspirational motivation, intellectual stimulation, and individualized consideration, have a very significant influence on the principal as the object of research. The implementation of the principal's transformational leadership can be carried out with a high commitment to advancing the school, increasing his or her integrity, having to read a lot in order to have high knowledge, and having to help teachers and staff who are having difficulties.

\section{REFERENCES}

1. Alalfi,RHany.(2015). SomeModern TrendsinEducational Leadership and Its Role in Developing the Performance of the Egyptian Secondary School Managers. American Journal of Educational Research, 2015, Vol. 3, No. 6, 689696http://pubs.sciepub.com/education/3/6/4.

2. Barling, J., Christie, A., \&Hoption, A. (2010). Leadership. In S. Zedeck (Ed.), Handbook of Industrial and Organizational Psychology, 183-240.

3. Bush, T., dan Middlewood, D. (2005). Leading and Managing People in Education. London: Sage Publication.

4. Cheng, Y. C. (2001). New Vision of School Based Management: Globalization, Localization, and Individualization. (http://home.ied.edu.hk/ vccheng/ doc /speeches/1-6spr01.doc).

5. Dagisthani, Bulquess Ismail Abdul Majid. (2017). The Saudi Little Leaders: The Current Status of Child's Participation Through Class and School Councils "Alshura Council" in Saudi Arabia. European Journal of Educational Sciences, EJES, Vol.4, No.2. (http://dx.doi. org/10.19044/ejes.v4no2a4).

6. Hughes, Ginnet, dan Curphy. (2012. Leadership: Enhancing the Lessons of Experience. Terjemahan Putri Iva Izzati. Jakarta: Salemba Humanika.

7. Jonyo, Dorothy Owuordan Bonn OderaJonyo. (2017). Teacher Management: Emerging Issues in Kenya. European Journal of Educational Sciences, EJES, Vol.4, No.1. http://dx.doi.org/10.19044/ejes.v4no1a18.
8. Kim, Minhyun. (2017). The Effect of Transformational Leadership on Middle School Students' Intrinsic Motivation and Expectancy-Value in Physical Education. European Journal of Educational Sciences, EJES, Vol.4, No.2. http://dx.doi.org/10.19044/ejes.v4no2a2.

9. Kim, B.Y. (2010). Application of Transformational Leadership: The Case of Hiddink Leadership. The Korean Association of Sport Law, 13 (1), 11-37.

10. Komariah, Aan dan Cepi Triatna. (2006). Visionary Leadership: Menuju Sekolah Efektif. Jakarta: Bumi Aksara.

11. Leithwood, K. and Jantzi, D. (2015). Explaining Variation in Teachers' Perceptions of Principals' Leadership: A Replication. Journal of Educational Administration. 35 (4).

12. Northouse. (2013). Kepemimpinan: Teori dan Praktik, Edisi Keenam. Jakarta: Indeks.

13. Raihani. (2010). Kepemimpinan Sekolah Transformatif. Yogyakarta: LKis.

14. Sergiovanni, T.J. (1990). Value-Added Leadership. New York: Harcourt Brace Javanovich.

15. Sugiyono. (2012). Memahami Penelitian Kualitatif. Bandung: Alfabeta.

16. Spadaro, Gabriela Scartascini, et al. 2017 Education as a Strategy for Sustainability in the 21st Century: Teachers as Creators of Educational Change. European Journal of Educational Sciences, EJES, Vol.4, No.4. (http://dx.doi. org/10.19044/ejes.v4no4a5).

17. Yu, H., et al. (2002). The Effect of Transformational Leadership on Teachers Commitment to Change in Hongkong. Journal of Educational Administration. 40 (4).

18. Yuldirim, Bilal. (2017). The Relationship between Principals' Leadership Practices and Teachers' WorkLife Balance. International Online Journal of Educational Sciences, 2017, 9 (3), 755 - 767.

Citation: Jusrin Efendi Pohan, Edy Suprayetno, "Transformational Leadership of the Principal on School Performance in Indonesia", American Research Journal of Humanities and Social Sciences, Vol 7, no. 1, 2021, pp. 1-5.

Copyright (C) 2021 Jusrin Efendi Pohan, Edy Suprayetno, This is an open access article distributed under the Creative Commons Attribution License, which permits unrestricted use, distribution, and reproduction in any medium, provided the original work is properly cited. 